\title{
EFFECT OF METHIONINE DEFICIENCY ON OXIDATIVE STRESS AND APOPTOSIS IN THE SMALL INTESTINE OF BROILERS
}

\author{
Tao RUAN ${ }^{1}$, Lingjun $\mathrm{LI}^{1}$, Yingnan LYU ${ }^{4}$, Qin $\mathrm{LUO}^{3}$ and Bangyuan $\mathrm{WU}^{1,2^{*}}$ \\ ${ }^{1}$ College of Life Science, China West Normal University, Shida road 1\#, Nanchong, \\ Sichuan, PR China; ${ }^{2}$ Key Laboratory of Southwest China Wildlife Resources Conserva- \\ tion, Ministry of Education, Nanchong, Sichuan, PR China; ${ }^{3}$ College of Veterinary Med- \\ icine, Sichuan Agricultural University, Chengdu, Sichuan, PR China; ${ }^{4}$ Department of \\ Microbiology and Immunology, National University of Singapore, Singapore
}

(Received 27 July 2017; accepted 12 February 2018)

\begin{abstract}
The aim of this study was to investigate the effects of methionine (Met) deficiency on antioxidant functions (in the duodenal, jejunal and ileal mucosa) and apoptosis in the duodenum, jejunum and ileum of broiler chickens. A total of 120 one-day-old Cobb broilers were divided into two groups and fed a Metdeficient diet and a control diet, respectively, for six weeks. The activities of superoxide dismutase (SOD), catalase (CAT) and glutathione peroxidase (GSH-Px), the ability to inhibit hydroxyl radicals, and glutathione (GSH) content were significantly decreased in the Met-deficient group compared to the control. In contrast, malondialdehyde (MDA) content was significantly higher in the Met-deficient group. As measured by terminal deoxynucleotidyl transferase 2'-deoxyuridine 5'triphosphate dUTP nick end-labelling (TUNEL) and flow cytometry (FCM), the percentages of apoptotic cells were significantly increased. In conclusion, dietary Met deficiency can cause oxidative stress and then induce increased apoptosis in the intestine. Oxidative stress contributes to intestinal apoptosis. This results in the impairment of local intestinal mucosal immunity due to oxidative stress and apoptosis in the small intestine. The results of this study provide new experimental evidence for understanding the negative effects of Met deficiency on mucosal immunity or the functions of other immune tissues.
\end{abstract}

Key words: Methionine deficiency, small intestine, oxidative stress, apoptosis, broilers

As a sulphur-containing amino acid, methionine (Met) performs a wide variety of biological functions (Avila et al., 2000; Yang et al., 2004; Oz et al., 2008) including growth promotion (Yen et al., 2002; Mirzaaghatabar et al., 2011), detoxification (Kim et al., 2006), antitumour function (Horvat et al., 2006; Li et al., 2009), resistance to coccidial infection (Rama Rao et al., 2003), involvement in methyl transfer (Stadtman, 2002; Waterland et al., 2006; Sanchez-

*Corresponding author; E-mail: wubangyuan2008@163.com 
Roman et al., 2011), influence on protein synthesis (Waterlow, 1996; Brosnan and Brosnan, 2006; Tesseraud et al., 2011; Li et al., 2014) and impact on the oxidative status of cells (Tesseraud et al., 2009; Tang et al., 2015). Apart from these functions, Met is also involved in avian immune function (Swain and Johri, 2000; Wu et al., 2013) and nutrient digestibility in the intestine of chickens (Adeniji et al., 2015).

The small intestine serves as the principal site for the digestion and absorption of nutrients, electrolytes and water from the intestinal lumen, and for the secretion of enzymes or transporters. The mucosal immune system is very important for host defence as well (Hecht, 2003; Ahmad et al., 2012). The intestine has another important function, intestinal immunity (Jeurissen et al., 2002). The intestinal mucosa displays complex defence mechanisms and plays a unique key role in mucosal immunity (Vervelde and Jeurissen, 2003; Deitch, 1990; Halliwell et al., 2000). Our previous studies proved that dietary Met deficiency can induce damage of the immune organs in broilers (Wu et al., 2012a, b, 2013). However, the effects of Met on gut function remain poorly documented. Thus, the aims of the present study were to investigate the role of Met in oxidative stress and cellular apoptosis in the intestine of broilers, and to provide new experimental evidence on the influence of Met deficiency on small intestinal functions in broilers. The present research could also provide useful insights for similar studies in both humans and in animal species other than chickens in the future.

\section{Materials and methods}

\section{Animals and diets}

One hundred and twenty one-day-old healthy Cobb broilers were allotted by body weight to two separate treatment groups of 60 broilers each. The broilers were fed either a control or a Met-deficient diet (as shown in Table 1). They were housed in cages with electrical heaters and were provided feed and water ad libitum for 42 days. The experimental diets were formulated according to the NRC recommendations (1994). The research and the use of animals complied with the guidelines of China West Normal University Animal Care Committee, and the environment and facilities of the laboratory animals were in line with the national standard (Chinese, GB4925-2010). 
RUAN et al

Table 1

Components of the basal diets for broilers (\%)

\begin{tabular}{|c|c|c|c|c|}
\hline \multirow[b]{2}{*}{ Ingredients $^{1}(\%)$} & \multicolumn{2}{|c|}{ Methionine-deficient diet } & \multicolumn{2}{|c|}{ Control diet } \\
\hline & $\begin{array}{l}\text { Starter diet } \\
1 \text { to } 21 \mathrm{~d}\end{array}$ & $\begin{array}{l}\text { Grower diet } \\
22 \text { to } 42 \mathrm{~d}\end{array}$ & $\begin{array}{l}\text { Starter diet } \\
1 \text { to } 21 \mathrm{~d}\end{array}$ & $\begin{array}{l}\text { Grower diet } \\
22 \text { to } 42 \mathrm{~d}\end{array}$ \\
\hline Ground yellow corn & 56 & 59.5 & 56 & 59.5 \\
\hline Soybean meal & 37 & 32.85 & 37 & 32.85 \\
\hline Soybean oil & 3.66 & 4.7 & 3.66 & 4.7 \\
\hline Ground limestone & 0.57 & 0.5 & 0.57 & 0.5 \\
\hline Dicalcium phosphate & 1.8 & 1.6 & 1.8 & 1.6 \\
\hline Salt & 0.3 & 0.3 & 0.3 & 0.3 \\
\hline Choline chloride & 0.1 & 0.1 & 0.1 & 0.1 \\
\hline DL-Met & 0.0 & 0.0 & 0.24 & 0.12 \\
\hline Bentonite & 0.24 & 0.12 & 0.0 & 0.0 \\
\hline Micronutrients $^{2}$ & 0.33 & 0.33 & 0.33 & 0.33 \\
\hline \multicolumn{5}{|c|}{ Calculated nutrient levels (\%) } \\
\hline $\mathrm{ME}, \mathrm{MJ} / \mathrm{kg}$ & 12.39 & 12.79 & 12.39 & 12.79 \\
\hline $\mathrm{CP}$ & 21.17 & 19.72 & 21.17 & 19.72 \\
\hline Lys & 1.19 & 1.08 & 1.19 & 1.08 \\
\hline Met & 0.26 & 0.28 & 0.50 & 0.40 \\
\hline Met + Cys & 0.62 & 0.50 & 0.74 & 0.62 \\
\hline $\mathrm{Ca}$ & 0.85 & 0.77 & 0.85 & 0.77 \\
\hline Nonphytate $\mathrm{P}$ & 0.44 & 0.40 & 0.44 & 0.40 \\
\hline
\end{tabular}

${ }^{1}$ Ingredients and nutrient composition are reported on as-fed basis. ${ }^{2}$ For the diet of d 1-21 and d 22-42, provided per kilogram of diet: vitamin A (all-trans retinol acetate), 12,500 IU; cholecalciferol, 2,500 IU; vitamin E (all-rac- $\alpha$-tocopherol acetate), $18.75 \mathrm{IU}$; vitamin $\mathrm{K}$ (menadione Na bisulfate), $5.0 \mathrm{mg}$; thiamin (thiamin mononitrate), $2.5 \mathrm{mg}$; riboflavin, $7.5 \mathrm{mg}$; vitamin $\mathrm{B}_{6}, 5.0 \mathrm{mg}$; vitamin $\mathrm{B}_{12}, 0.0025 \mathrm{mg}$; pantothenate, $15 \mathrm{mg}$; niacin, $50 \mathrm{mg}$; folic acid, $1.25 \mathrm{mg}$; biotin, $0.12 \mathrm{mg}$; $\mathrm{Cu}\left(\mathrm{CuSO}_{4} \times 5 \mathrm{H}_{2} \mathrm{O}\right), 10 \mathrm{mg} ; \mathrm{Mn}\left(\mathrm{MnSO}_{4} \times \mathrm{H}_{2} \mathrm{O}\right), 100 \mathrm{mg} ; \mathrm{Zn}\left(\mathrm{ZnSO}_{4} \times 7 \mathrm{H}_{2} \mathrm{O}\right), 100 \mathrm{mg} ; \mathrm{Fe}$ $\left(\mathrm{FeSO}_{4} \times 7 \mathrm{H}_{2} \mathrm{O}\right), 100 \mathrm{mg} ; \mathrm{I}(\mathrm{KI}), 0.4 \mathrm{mg} ; \mathrm{Se}\left(\mathrm{Na}_{2} \mathrm{SeO}_{3}\right), 0.2 \mathrm{mg}$

Determination of oxidative stress parameters in the small intestine by biochemical methods

On days 14, 28 and 42, six broilers each in both groups were humanely sacrificed for observations and measurements. The small intestines were immediately removed and chilled to $0{ }^{\circ} \mathrm{C}$ in $0.85 \%$ sodium chloride $(\mathrm{NaCl})$ solution, and divided into duodenum, jejunum, and ileum. An approximately 4-cm-long intestinal segment was collected from the middle section of each intestinal region, and then dissected and thoroughly cleaned with $0.85 \% \mathrm{NaCl}$ solution. The mucosa was carefully scraped from the luminal face of the collected intestinal segments and stored at $-80^{\circ} \mathrm{C}$ prior to the measurements. Total protein quantity in the supernatant (per milligram or gram) of the intestinal homogenate was determined using Bradford's method (Bradford, 1976). The activities of superoxide 
dismutase (SOD), catalase (CAT) and glutathione peroxidase (GSH-Px), the ability to inhibit hydroxyl radicals (AIHR), and the contents of glutathione (GSH) and malondialdehyde (MDA) in the supernatant were detected by biochemical methods following the instructions of the reagent kits (SOD assay kit, Cat. No.: A001-1; CAT assay kit, Cat. No.: A007-2; GSH-Px assay kit, Cat. No.: A005; AIHR assay kit, Cat. No.: A018; GSH assay kit, Cat. No.: A006-1; MDA assay kit, Cat. No.: A003-2, purchased from Nanjing Jiancheng Bioengineering Institute of China, Nanjing, China). The absorbance of SOD, CAT, GSH-Px, the abilities to inhibit hydroxyl radical, GSH and MDA were measured by hydroxylamine method, ultraviolet, colorimetric method, hydroxylamine method, spectrophotometric method and thiobarbituric acid (TBA) method, respectively, and at $550 \mathrm{~nm}, 240 \mathrm{~nm}, 412 \mathrm{~nm}, 550 \mathrm{~nm}, 532 \mathrm{~nm}$ and $420 \mathrm{~nm}$, respectively, under a microtitre plate reader (Thermo, Varioskan Flash, USA).

\section{Detection of intestinal apoptosis by TUNEL and flow cytometry (FCM)}

TUNEL method. The middle section of the duodenum, jejunum and ileum were collected and fixed in 10\% neutral buffered formalin after postmortem examination, and then processed, trimmed, and embedded in paraffin. The terminal deoxynucleotidyl transferase 2'-deoxyuridine 5'-triphosphate dUTP nick endlabelling (TUNEL) assay was performed in $5 \mu \mathrm{m}$ thick dewaxed sections with an Apoptosis Detection Kit (Cat. No.: QIA33, Merck, Germany) according to the manufacturer's instructions, as described by Peng et al. (2009).

Flow cytometry (FCM method). The mucosa was carefully scraped from the luminal face of the collected intestinal segments as described above, and ground to form a cell suspension that was filtered through a 300-mesh nylon screen. The cells were washed twice with cold phosphate-buffered saline solution (PBS, pH 7.2-7.4) and suspended in $1 \times$ binding buffer (Cat. No.: 51-66121E) at a concentration of $1 \times 10^{6}$ cells $/ \mathrm{mL}$. Subsequently, $100 \mu \mathrm{L}$ of the cell suspension was transferred to 5 -mL culture tubes, followed by the addition of $5 \mu \mathrm{L}$ of Annexin V-FITC (Cat. No.: 51-65874X) and $5 \mu \mathrm{L}$ of propidium iodide (Cat. No.: 51-66211E). The mixture was gently vortexed and incubated at $25^{\circ} \mathrm{C}$ in the dark for $15 \mathrm{~min}$. Four hundred $\mu \mathrm{L}$ of $1 \times$ binding buffer was added to each tube, and finally analysis by flow cytometry on a BD FACSCalibur platform (BD Biosciences, Singapore) was conducted within $1 \mathrm{~h}$.

\section{Statistical analysis}

Data (the mean data of the two groups) of the control and the Metdeficient groups were statistically evaluated with independent-samples $t$-test using SPSS 11.0 software package program for Windows, first using the general linear model and next the single variable, then the dependent variable was used to analyse the statistics. All results were expressed as means \pm standard devia- 
tion, representing six broilers in each group. Differences between means were assessed, and values of $\mathrm{P}<0.05$ and $\mathrm{P}<0.01$ were considered significant and highly significant, respectively.

\section{Results}

\section{Changes of oxidative stress parameters}

Changes in SOD activity. As shown in Table 2, no significant changes in SOD activity were observed in the Met-deficient group in the duodenum, jejunum and ileum at 14 days of age. However, SOD activities were significantly or highly significantly lower $(\mathrm{P}<0.05$ or $\mathrm{P}<0.01)$ in the Met-deficient group than in the control at 28 days of age, and highly significantly lower $(\mathrm{P}<0.01)$ in all of the three intestinal segments at 42 days of age.

\section{Table 2}

Changes of superoxide dismutase (SOD) activities (U/mg protein) in the duodenum, jejunum and ileum of broiler chickens

\begin{tabular}{llccc}
\hline Intestine & \multicolumn{1}{c}{ Groups } & \multicolumn{1}{c}{14 days } & \multicolumn{1}{c}{28 days } & \multicolumn{1}{c}{42 days } \\
\hline Duodenum & Control & $61.06 \pm 5.23$ & $67.13 \pm 4.86$ & $64.77 \pm 3.96$ \\
& Met-deficient & $61.97 \pm 4.54$ & $60.03 \pm 3.97^{*}$ & $55.95 \pm 3.48^{* *}$ \\
\multirow{2}{*}{ Jejunum } & Control & $57.25 \pm 4.66$ & $58.67 \pm 3.78$ & $58.04 \pm 4.26$ \\
& Met-deficient & $56.27 \pm 4.51$ & $52.81 \pm 1.89^{*}$ & $46.43 \pm 4.39^{* *}$ \\
\multirow{2}{*}{ Ileum } & Control & $58.71 \pm 4.53$ & $61.53 \pm 3.71$ & $59.98 \pm 3.87$ \\
& Met-deficient & $56.12 \pm 3.36$ & $55.34 \pm 4.33^{* *}$ & $51.35 \pm 4.21^{* *}$ \\
\hline
\end{tabular}

Data are presented as means \pm standard deviation $(\mathrm{n}=6)$; Met $=$ methionine; ${ }^{*} \mathrm{P}<0.05$ compared to the control group; ${ }^{* *} \mathrm{P}<0.01$ compared to the control group

Changes in CAT activity. At 14 days of age, the activities of CAT in the jejunum were reduced $(\mathrm{P}<0.05)$ in the Met-deficient group compared to those in the control, but there were no significant changes in the duodenum and ileum. The activities of CAT in the duodenum, jejunum and ileum were significantly reduced $(\mathrm{P}<0.05)$ in the Met-deficient group at 28 days of age, and were significantly or highly significantly reduced $(\mathrm{P}<0.05$ or $\mathrm{P}<0.01)$ at 42 days of age, as shown in Table 3.

Changes in GSH-Px activity. Compared to the GSH-Px activities found in the duodenum, jejunum and ileum in the control group, there were no significant changes in GSH-Px activity in the Met-deficient group at 14 days of age. However, the GSH-Px activities in all of the three segments of the small intestine in the Metdeficient group were significantly lower $(\mathrm{P}<0.05$ or $\mathrm{P}<0.01)$ at 28 days of age, and they were highly significantly lower $(\mathrm{P}<0.01)$ at 42 days of age (Table 4$)$. 
Table 3

Changes of catalase (CAT) activities (U/g protein) in the duodenum, jejunum and ileum of broiler chickens

\begin{tabular}{lllll}
\hline Intestine & \multicolumn{1}{c}{ Groups } & \multicolumn{1}{c}{14 days } & 28 days & 42 days \\
\hline Duodenum & Control & $411.32 \pm 15.54$ & $404.67 \pm 12.34$ & $399.56 \pm 9.75$ \\
& Met-deficient & $405.44 \pm 21.12$ & $384.83 \pm 13.41^{*}$ & $379.77 \pm 11.75^{*}$ \\
\multirow{2}{*}{ Jejunum } & Control & $402.55 \pm 15.13$ & $398.37 \pm 13.76$ & $398.56 \pm 12.87$ \\
& Met-deficient & $385.46 \pm 14.43^{*}$ & $383.78 \pm 14.65^{*}$ & $372.53 \pm 13.31^{* *}$ \\
Ileum & Control & $407.35 \pm 16.31$ & $411.36 \pm 12.66$ & $414.92 \pm 9.97$ \\
& Met-deficient & $399.756 \pm 20.12$ & $389.63 \pm 10.55^{*}$ & $378.31 \pm 8.917^{* *}$ \\
\hline
\end{tabular}

Data are presented as means \pm standard deviation $(n=6)$; Met $=$ methionine; ${ }^{*} \mathrm{P}<0.05$ compared to the control group; ${ }^{* *} \mathrm{P}<0.01$ compared to the control group

Table 4

Changes of glutathione peroxidase (GSH-Px) activities (U/g protein) in the duodenum, jejunum and ileum of broiler chickens

\begin{tabular}{|c|c|c|c|c|}
\hline Intestine & Groups & 14 days & 28 days & 42 days \\
\hline Duodenum & $\begin{array}{l}\text { Control } \\
\text { Met-deficient }\end{array}$ & $\begin{array}{l}121.44 \pm 4.43 \\
116.75 \pm 7.73\end{array}$ & $\begin{aligned} 119.43 & \pm 6.72 \\
98.65 & \pm 5.66^{*}\end{aligned}$ & $\begin{aligned} 123.86 & \pm 6.65 \\
89.87 & \pm 4.53^{* *}\end{aligned}$ \\
\hline Jejunum & $\begin{array}{l}\text { Control } \\
\text { Met-deficient }\end{array}$ & $\begin{array}{l}109.26 \pm 7.50 \\
105.47 \pm 3.33\end{array}$ & $\begin{aligned} 113.41 & \pm 3.78 \\
92.61 & \pm 3.58^{* *}\end{aligned}$ & $\begin{aligned} 118.11 & \pm 3.21 \\
88.94 & \pm 3.88^{* *}\end{aligned}$ \\
\hline Ileum & $\begin{array}{l}\text { Control } \\
\text { Met-deficient }\end{array}$ & $\begin{array}{l}110.17 \pm 5.21 \\
105.23 \pm 3.50\end{array}$ & $\begin{array}{r}104.34 \pm 4.14 \\
90.44 \pm 2.56^{*}\end{array}$ & $\begin{aligned} 109.59 & \pm 3.87 \\
86.75 & \pm 4.66^{* *}\end{aligned}$ \\
\hline
\end{tabular}

Data are presented as means \pm standard deviation $(\mathrm{n}=6)$; Met $=$ methionine; ${ }^{*} \mathrm{P}<0.05$ compared to the control group; ${ }^{* *} \mathrm{P}<0.01$ compared to the control group

Change in the ability to inhibit hydroxyl radicals. The results in Table 5 show that the ability to inhibit hydroxyl radicals was lower $(\mathrm{P}<0.05)$ only in the jejunum of the Met-deficient group than in the control at 14 days of age. However, at 28 and 42 days of age, the ability to inhibit hydroxyl radicals in the duodenum, jejunum and ileum showed a varying but significant decrease $(\mathrm{P}<0.05$ or $\mathrm{P}<0.01)$ in the Met-deficient group as compared to the control.

Changes in GSH content. At 14 days of age, only the GSH content of the duodenum was reduced $(\mathrm{P}<0.05)$ in the Met-deficient group as compared to the control. However, at 28 and 42 days of age, the GSH contents of all of the three intestinal segments were significantly decreased $(\mathrm{P}<0.05$ or $\mathrm{P}<0.01)$ in the Met-deficient group (Table 6). 
RUAN et al

Table 5

Change of the ability to inhibit hydroxyl radicals (U/mg protein) in the duodenum, jejunum and ileum of broiler chickens

\begin{tabular}{|c|c|c|c|c|}
\hline Intestine & Groups & 14 days & 28 days & 42 days \\
\hline \multirow[t]{2}{*}{ Duodenum } & Control & $171.66 \pm 6.66$ & $165.56 \pm 4.78$ & $180.21 \pm 6.71$ \\
\hline & Met-deficient & $170.48 \pm 4.98$ & $156.10 \pm 3.94^{*}$ & $163.30 \pm 5.33^{*}$ \\
\hline \multirow[t]{2}{*}{ Jejunum } & Control & $167.32 \pm 5.57$ & $169.42 \pm 5.11$ & $171.60 \pm 4.56$ \\
\hline & Met-deficient & $148.41 \pm 5.24^{*}$ & $151.30 \pm 5.22^{* *}$ & $153.61 \pm 4.30^{* *}$ \\
\hline \multirow[t]{2}{*}{ Ileum } & Control & $151.34 \pm 5.37$ & $154.36 \pm 4.22$ & $155.33 \pm 5.19$ \\
\hline & Met-deficient & $148.77 \pm 4.21$ & $143.14 \pm 3.97^{*}$ & $136.03 \pm 4.51^{* *}$ \\
\hline
\end{tabular}

Data are presented as means \pm standard deviation $(\mathrm{n}=6)$; Met $=$ methionine; ${ }^{*} \mathrm{P}<0.05$ compared to the control group; ${ }^{* *} \mathrm{P}<0.01$ compared to the control group

Table 6

Changes of glutathione (GSH) content (mg/g protein) in the duodenum, jejunum and ileum of broiler chickens

\begin{tabular}{lllll}
\hline Intestine & \multicolumn{1}{c}{ Groups } & \multicolumn{1}{c}{14 days } & 28 days & 42 days \\
\hline \multirow{2}{*}{ Duodenum } & Control & $4.65 \pm 0.33$ & $4.38 \pm 0.31$ & $3.46 \pm 0.41$ \\
& Met-deficient & $4.07 \pm 0.19^{*}$ & $3.46 \pm 0.41^{*}$ & $2.53 \pm 0.36^{*}$ \\
\multirow{2}{*}{ Jejunum } & Control & $3.92 \pm 0.32$ & $3.73 \pm 0.149$ & $2.97 \pm 0.27$ \\
& Met-deficient & $3.86 \pm 0.28$ & $2.35 \pm 0.22^{* *}$ & $1.47 \pm 0.33^{* *}$ \\
Ileum & Control & $3.49 \pm 0.29$ & $3.38 \pm 0.38^{*}$ & $2.76 \pm 0.32^{* *}$ \\
& Met-deficient & $3.27 \pm 0.19$ & $2.66 \pm 0.44^{*}$ & $1.43 \pm 0.38^{*}$ \\
\hline
\end{tabular}

Data are presented as means \pm standard deviation $(\mathrm{n}=6)$; Met $=$ methionine; ${ }^{*} \mathrm{P}<0.05$ compared to the control group; ${ }^{* *} \mathrm{P}<0.01$ compared to the control group

Changes in MDA content. The results in Table 7 show that the MDA content of the ileum was increased $(\mathrm{P}<0.05)$ in the Met-deficient group at 14 days of age when compared to that of the control. The MDA contents in the duodenum, jejunum and ileum of the Met-deficient group were all significantly increased $(\mathrm{P}<0.05)$ at 28 days of age, and significantly or highly significantly increased $(\mathrm{P}<0.05$ or $\mathrm{P}<0.01)$ at 42 days of age.

\section{Changes in small intestinal apoptosis}

Changes in the number of apoptotic cells determined by the TUNEL assay. Apoptotic cells had brown-stained nuclei with condensed and irregular morphologic changes. Apoptotic cells were mainly distributed in the lamina propria and the epithelial layer (Fig. 1). As shown in Histogram 1, there were no significant 
changes in the number of apoptotic cells in the Met-deficient group in the duodenum, jejunum and ileum at 14 days of age, only a tendency of increase was demonstrated; however, significantly higher $(\mathrm{P}<0.05$ or $\mathrm{P}<0.01)$ numbers of apoptotic cells were detected in the Met-deficient group in the duodenum and jejunum at 28 days of age, and the number of apoptotic cells in the ileum was significantly higher $(\mathrm{P}<0.01)$ at 42 days of age as compared to control.

Table 7

Changes of malondialdehyde (MDA) content (nmol/mg protein) in the duodenum, jejunum and ileum of broiler chickens

\begin{tabular}{lllll}
\hline Intestine & \multicolumn{1}{c}{ Groups } & \multicolumn{1}{c}{14 days } & \multicolumn{1}{c}{28 days } & 42 days \\
\hline Duodenum & Control & $1.47 \pm 0.18$ & $1.50 \pm 0.31$ & $1.89 \pm 0.22$ \\
& Met-deficient & $1.76 \pm 0.31$ & $2.34 \pm 0.35^{*}$ & $2.45 \pm 0.23^{*}$ \\
\multirow{2}{*}{ Jejunum } & Control & $2.06 \pm 0.13$ & $1.99 \pm 0.28$ & $2.26 \pm 0.37$ \\
& Met-deficient & $2.30 \pm 0.33$ & $2.81 \pm 0.32^{*}$ & $3.43 \pm 0.23^{* *}$ \\
Ileum & Control & $1.46 \pm 0.16$ & $1.50 \pm 0.31$ & $1.62 \pm 0.20$ \\
& Met-deficient & $1.95 \pm 0.34^{*}$ & $2.27 \pm 0.35^{*}$ & $2.49 \pm 0.23^{* *}$ \\
\hline
\end{tabular}

Data are presented as means \pm standard deviation $(\mathrm{n}=6)$; Met $=$ methionine; ${ }^{*} \mathrm{P}<0.05$ compared to the control group; ${ }^{* *} \mathrm{P}<0.01$ compared to the control group

Percentage of apoptotic cells determined by flow cytometry. Flow cytometry was used to quantitatively determine the percentage of cells within a population that were actively undergoing apoptosis (Fig. 2). As shown in Histogram 2, at 14 days of age, this percentage tended to increase in the duodenum and ileum, but the differences were not statistically significant. The percentages of apoptotic cells in the duodenum and ileum were significantly elevated $(\mathrm{P}<0.05$ or $\mathrm{P}<$ 0.01 ) in the Met-deficient group compared to the control at 28 and 42 days of age. The percentages of apoptotic cells in the jejunum were significantly elevated $(\mathrm{P}<0.05$ or $\mathrm{P}<0.01)$ in the Met-deficient group at 14,28 and 42 days of age.

\section{Discussion}

The intestinal mucosa is vulnerable to oxidative damage due to its constant exposure to reactive oxygen species (ROS) generated by the luminal content (Deitch, 1990). Met acts as a key antioxidant factor pivotal to the protection of the intestinal mucosa. It has been reported that a variety of ROS readily react with Met residues in proteins to form methionine sulphoxide, thus scavenging the reactive oxygen species (Luo and Levine, 2009). In this study we found that Met deficiency led to intestinal oxidative damage in broilers. 

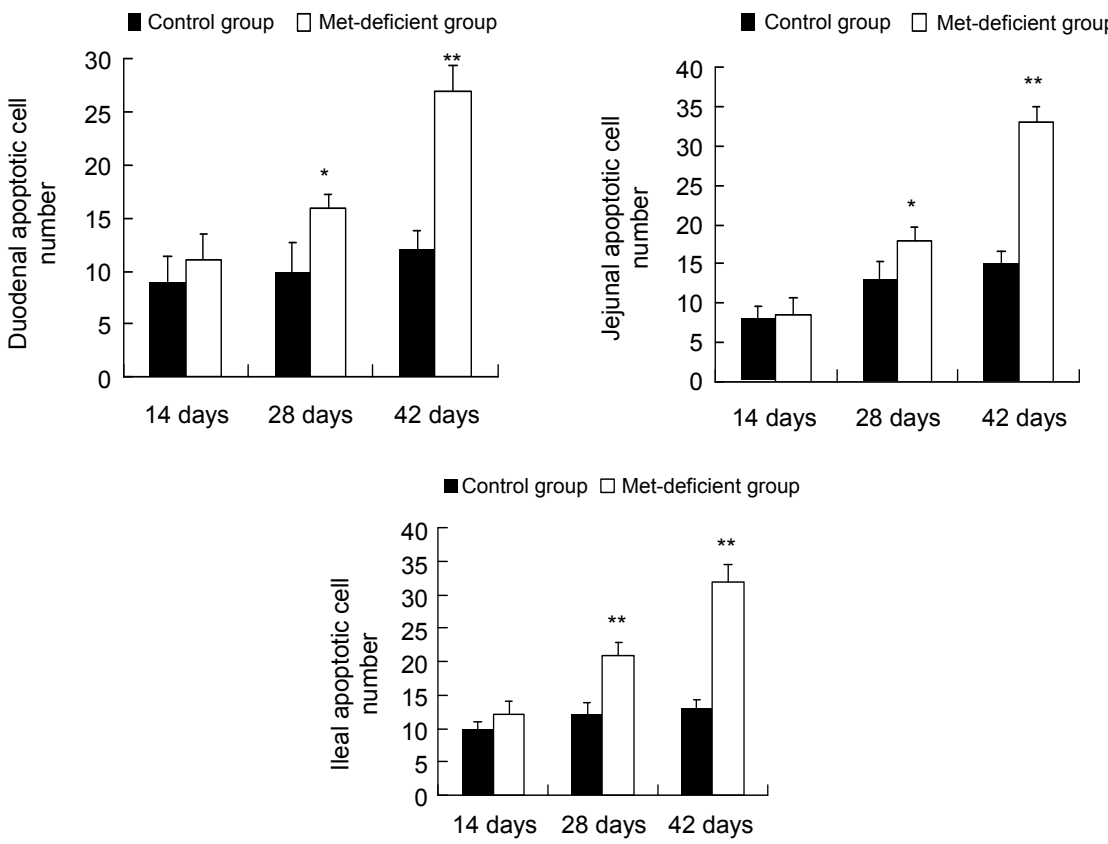

Histogram 1. Number of apoptotic cells measured by TUNEL in the duodenum (a), jejunum (b) and ileum (c) of broiler chickens

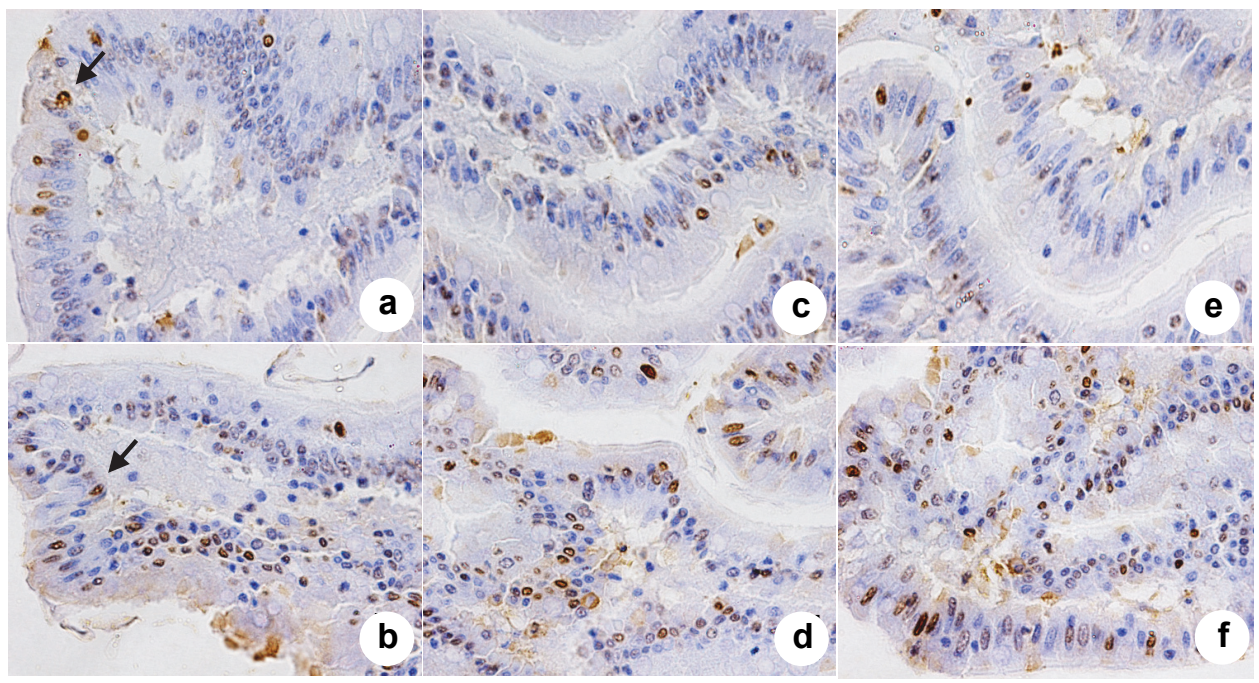

Fig. 1. Apoptotic cells in the duodenum (a and b), jejunum (c and d) and ileum (e and f) stained by

TUNEL at 42 days of age. The numbers of apoptotic cells are significantly increased in the Metdeficient group in the duodenum, jejunum and ileum (b, $\mathrm{d}$ and $\mathrm{f})$ as compared to those of the control groups (a, c and e). Apoptotic cells have brown-staining nuclei (arrow). Bar $=20 \mu \mathrm{m}$ 

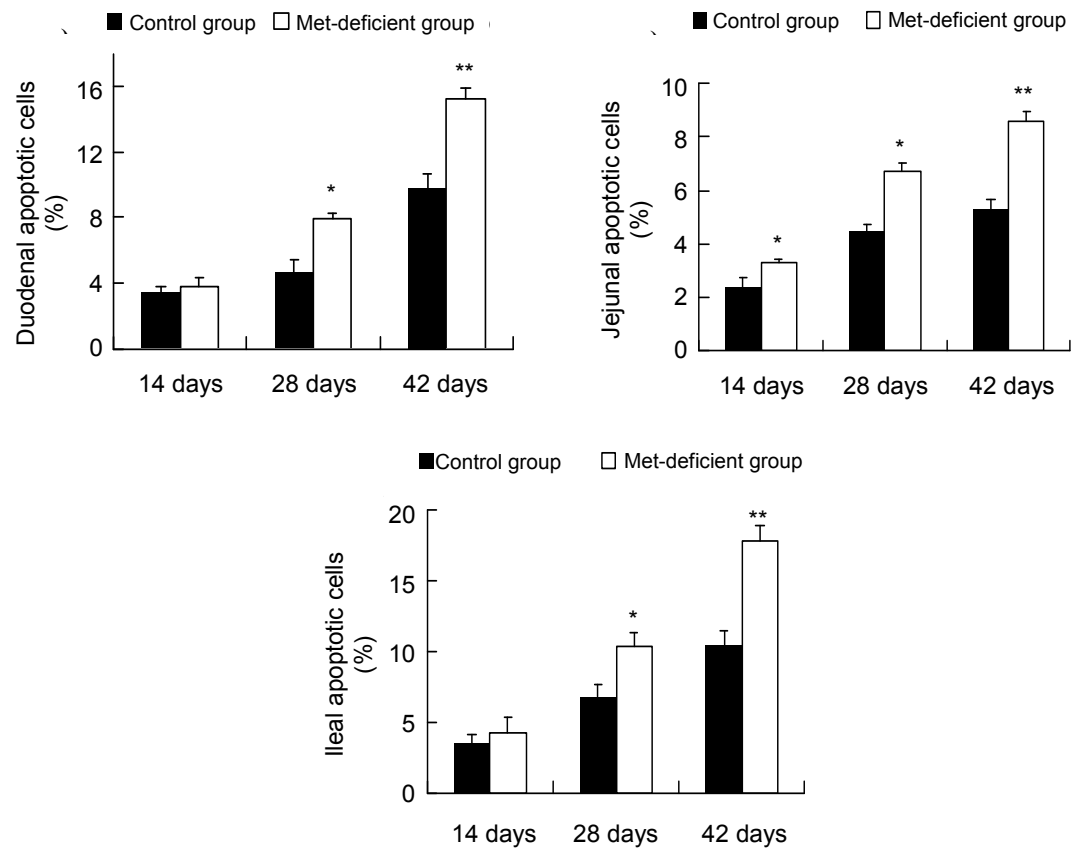

Histogram 2. The percentage of apoptotic cells determined by flow cytometry (FCM) in the duodenum (a), jejunum (b) and ileum (c)
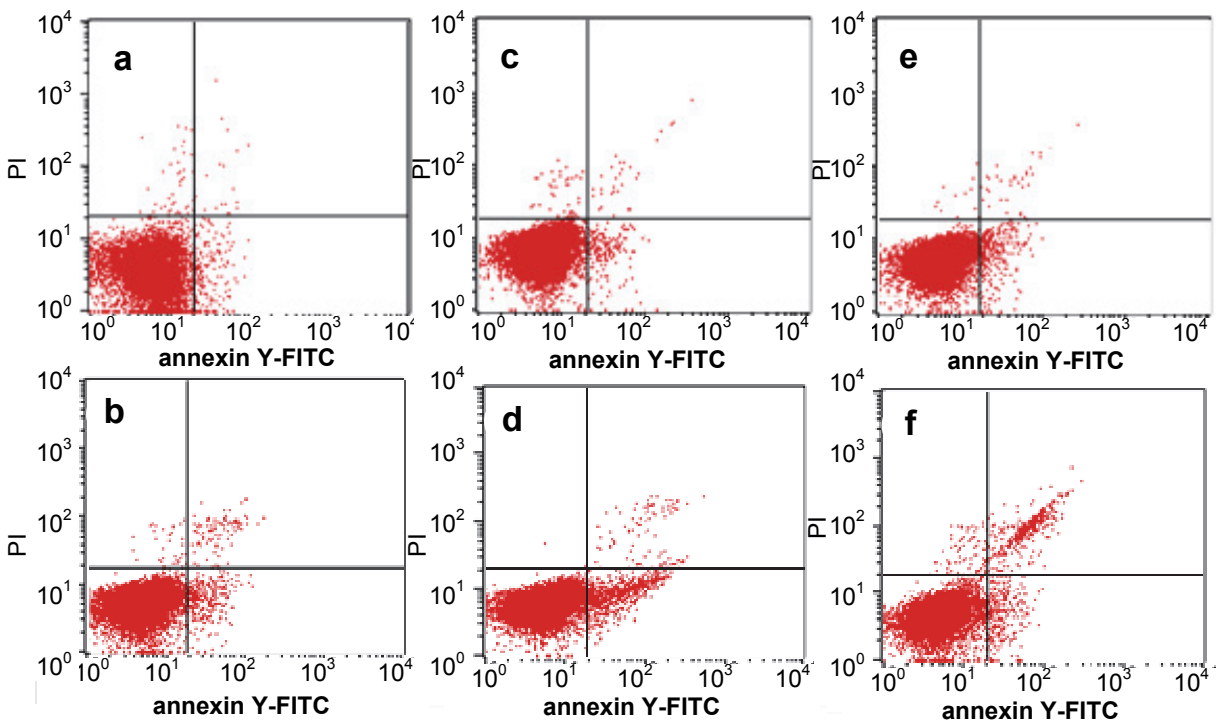

Fig. 2. Cells staining positive for annexin V-FITC and negative for propidium iodide (PI) are undergoing apoptosis. Quadrant diagram shows that a minor percentage of cells in the duodenum (a), jejunum (c) and ileum (e) of the control group are undergoing apoptosis, and an increased percentage of cells is undergoing apoptosis in the duodenum (b), jejunum (d) and ileum (f) of the Met-

deficient group 
Enhanced ROS generation can overwhelm intrinsic antioxidant cellular defences and result in a condition known as 'oxidative stress' (Halliwell et al., 2000). There are some antioxidants (including antioxidant enzymes and nonenzymatic antioxidants) that play a role in preventing oxidative stress (Adedara et al., 2010). In this study, the activities of SOD, GSH-Px and CAT, which antioxidant enzymes considered to be the first line of cellular defence against oxidative damage (Ferreccio et al., 1998), decreased in the Met-deficient group. SOD activity is in close connection with other antioxidant enzymes, such as GSH-Px and CAT, which decompose hydrogen peroxide (Naziroglu, 2009). Among the non-enzymatic antioxidants, GSH plays a primary role and is regarded as an early biological marker of oxidative stress (Gagliano et al., 2006). In our study, the GSH contents were significantly reduced; as a cellular antioxidant, GSH serves as a co-substrate for GSH-Px to maintain oxidative balance (Aw, 2005).

The decreased activities of the above enzymes can lead to an excessive availability of superoxide and hydrogen peroxide (Naziroglu, 2012). In the present study, it was found that the ability to inhibit hydroxyl radicals in the intestine was decreased in the Met-deficient group, implying that antioxidant function was impaired and caused oxidative stress. Additionally, an increased level of MDA was also found; MDA is one of the several low-molecular-weight end products of lipid peroxidation, which alters membrane fluidity and increases its fragility (Chen and Yu, 1994; Naziroglu, 2012). Moreover, high levels of MDA indicate the enhancement of lipid peroxidation and an accumulation of lipid peroxides and, thus, an impairment of antioxidative and other functions in the intestine. Most cells contain Met sulphoxide reductases and, consequently, Met residues may act as catalytic antioxidants, protecting both the protein where they are located and other macromolecules (Luo and Levine, 2009). Therefore, we assume that Met deficiency may negatively influence antioxidant capacity in the intestine. This could be a consequence of Met residue oxidation of the enzyme proteins, impairment of post-translation modification/activation of these enzymes or perhaps other cause(s). The higher rate of apoptosis suggests that activation of the Nrf2-ARE signal mechanism is impaired and another signal transmission pathway, e.g. NFkB, is activated, resulting in apoptosis. Further studies would be needed to clarify the exact pathways.

In this study, the TUNEL assay and flow cytometric assay revealed an increased percentage of cells undergoing apoptosis in the Met-deficient group, suggesting that dietary Met deficiency could induce apoptosis. Previous studies have clarified that oxidative stress could result in apoptosis (Kannan and Jain, 2000), and our results suggest that oxidative stress in the intestine was induced by Met deficiency, subsequently enhancing apoptosis. The present results may be helpful in explaining the pathogenesis of cellular apoptosis induced by Met deficiency. 
It is concluded that dietary Met deficiency results in a decrease of antioxidant enzyme activities, lower activity to inhibit hydroxyl radicals, and enhancement of lipid peroxidation, which consequently induce oxidative damage in the intestinal mucosa and result in cellular apoptosis in the intestine of broilers. Intestinal functions such as absorption and mucosal immunity are eventually impaired due to oxidative damage of the intestinal mucosa and cellular apoptosis. Oxidative damage-induced apoptosis may be the main mechanism underlying the effects of Met deficiency on intestinal health.

\section{Acknowledgements}

The authors would like to thank the co-workers of China West Normal University for their assistance in performing the experiment and the analysis. The study was supported by the programme for scientific research projects of China West Normal University (project no. 416370).

\section{References}

Adedara, I. A., Owumi, S. E., Uwaifo, A. O. and Farombi, E. O. (2010): Aflatoxin B1 and ethanol co-exposure induces hepatic oxidative damage in mice. Toxicol. Ind. Health 26, 717-724.

Adeniji, A. O., Ologhobo, A. D., Adebiyi, O. A. and Adejumo, I. O. (2015): Effect of methionine and organic acid on apparent nutrient utilization and gut morphology of broiler chicken. Adv. Res. 4, 87-93.

Ahmad, J., Ahamed, M., Akhtar, M. J., Alrokayan, S. A., Siddiqui, M. A., Musarrat, J. and AlKhedhairy, A. A. (2012): Apoptosis induction by silica nanoparticles mediated through reactive oxygen species in human liver cell line HepG2. Toxicol. Appl. Pharm. 259, 160-168.

Avila, M. A., Berasain, C., Torres, L., Martin-Duce, A., Corrales, F. J., Yang, H., Prieto, J., Lu, S. C., Caballeria, J., Rodes, J. and Mato, J. M. (2000): Reduced mRNA abundance of the main enzymes involved in methionine metabolism in human liver cirrhosis and hepatocellular carcinoma. J. Hepat. 33, 907-914.

Aw, T. Y. (2005): Intestinal glutathione: determinant of mucosal peroxide transport metabolism and oxidative susceptibility. Toxicol. Appl. Pharm. 204, 320-328.

Bradford, M. M. (1976): A rapid and sensitive method for the quantitation of microgram quantities of protein utilizing the principle of protein-dye binding. Anal. Biochem. 72, 248-254.

Brosnan, J. T. and Brosnan, M. E. (2006): The sulfur-containing amino acids: an overview. J. Nutr. 136, 1636S-1640S.

Chen, J. J. and Yu, B. P. (1994): Alteration in mitochondrial membrane fluidity by lipid peroxidation products. Free. Radical Biol. Med. 17, 411-418.

Deitch, E. A. (1990): The role of intestinal barrier failure and bacterial translocation in the development of systemic infection and multiple organ failure. Arch. Surg. 125, 403-404.

Ferreccio, C., Gonzalez, P. C., Milosavjlevic, S. V., Marshall, G. G. and Maria, S. A. (1998): Lung cancer and arsenic exposure in drinking water: a case control study in northern Chile. Cad. Saúde Pública 14, 193-198.

Gagliano, N., Dalle, D. I., Torri, C., Migliori, M., Grizzi, F., Milzani, A., Filippi, C., Annoni, G., Colombo, P., Costa, F., Ceva-Grimaldi, G., Bertelli, A., Giovannini, L. and Gioia, M. (2006): Early cytotoxic effects of ochratoxin A in rat liver: a morphological biochemical and molecular study. Toxicology 225, 214-224. 
Halliwell, B., Zhao, K. and Whiteman, M. (2000): The gastrointestinal tract: a major site of antioxidant action? Free Radical Res. 33, 819-830.

Hecht, G. A. (2003): Microbial pathogenesis and the intestinal epithelial cell. American Society for Microbiology, Washington. pp. 60-66.

Horvat, S., Mlinaric-Majerski, K., Glavas-Obrovac, L., Jakas, A., Veljkovic, J., Marczi, S., Kragol, G., Roscic, M., Matkovic, M. and Milostic-Srb, A. (2006): Tumor-cell-targeted methionine-enkephalin analogues containing unnatural amino acids: design synthesis and in vitro antitumor activity. J. Med. Chem. 49, 3136-3142.

Jeurissen, S., Lewis, F., van der Klis, J. D., Mroz, Z., Rebel, J. and Ter Huurne, A. (2002): Parameters and techniques to determine intestinal health of poultry as constituted by immunity integrity and functionality. Curr. Issues Intest. Microbiol. 3, 1-14.

Kannan, K. and Jain, S. K. (2000): Oxidative stress and apoptosis. Pathophysiology 7, 153-163.

Kim, W. K., Froelich, C. A., Patterson, P. H. and Ricke, S. C. (2006): The potential to reduce poultry nitrogen emissions with dietary methionine or methionine analogues supplementation. World Poultry Sci. J. 62, 338-353.

Li, C., Li, Z., Sletten, E., Arnesano, F., Losacco, M., Natile, G. and Liu, Y. (2009): Methionine can favor DNA platination by trans-coordinated platinum antitumor drugs. Angew. Chem. Int. Edit. 48, 8497-8500.

Li, G. W., Burkhardt, D., Gross, C. and Weissman, J. S. (2014): Quantifying absolute protein synthesis rates reveals principles underlying allocation of cellular resources. Cell 157, 624-635.

Luo, S. and Levine, R. L. (2009): Methionine in proteins defends against oxidative stress. FASED J. 23, 464-472.

Mirzaaghatabar, F., Saki, A. A., Zamani, P., Aliarabi, H. and Hemati Matin, H. R. (2011): Effect of different levels of diet methionine and metabolisable energy on broiler performance and immune system. Food Agric. Immunol. 22, 93-103.

Naziroglu, M. (2009): Role of selenium on calcium signaling and oxidative stress-induced molecular pathways in epilepsy. Neurochem. Res. 34, 2181-2191.

Naziroglu, M. (2012): Molecular role of catalase on oxidative stress-induced $\mathrm{Ca}^{2+}$ signaling and TRP cation channel activation in nervous system. J. Recept. Signal Transd. 32, 134-141.

NRC (1994): Nutrient Requirements of Poultry. Ninth revised edition. National Research Council, National Academy Press, Washington, D.C., 1994.

Oz, H., Chen, T. and Neuman, M. (2008): Methionine deficiency and hepatic injury in a steatohepatitis model. Digest. Dis. Sci. 53, 767-776.

Peng, X., Cui, Y., Cui, W., Deng, J. L. and Cui, H. M. (2009): The decrease of relative weight lesions and apoptosis of bursa of Fabricius induced by excess dietary selenium in chickens. Biol. Trace Elem. Res. 131, 33-42.

Rama Rao, S. V., Praharaj, N. K., Ramasubba Reddy, V. and Panda, A. K. (2003): Interaction between genotype and dietary concentrations of methionine for immune function in commercial broilers. Br. Poult. Sci. 44, 104-112.

Sanchez-Roman, I., Gomez, A., Gomez, J., Suarez, H., Sanchez, C., Naudi, A., Ayala, V., PorteroOtin, M., Lopez-Torres, M., Pamplona, R. and Barja, G. (2011): Forty percent methionine restriction lowers DNA methylation complex I ROS generation and oxidative damage to mtDNA and mitochondrial proteins in rat heart. J. Bioenerg. Biomembr. 43, 699-708.

Stadtman, E. R. (2002): Importance of individuality in oxidative stress and aging. Free Rad. Biol. Med. 33, 597-604.

Swain, B. K. and Johri, T. S. (2000): Effect of supplemental methionine, choline and their combinations on the performance and immune response of broilers. Br. Poult. Sci. 41, 83-88.

Tang, Y., Tan, B., Xiong, X., Li, F., Ren, W., Kong, X., Qiu, W., Hardwidge, P. R. and Yin, Y. (2015): Methionine deficiency reduces autophagy and accelerates death in intestinal epithelial cells infected with enterotoxigenic Escherichia coli. Amino Acids 47, 2199-2204.

Tesseraud, S., Everaert, N., Ezzine, S. B., Collin, A. and Berri, S. M. C. (2011): Manipulating tissue metabolism by amino acids. World Poultry Sci. J. 67, 243-252. 
Verwelde, L. and Jeurissen, S. H. M. (1993): Postnatal development of intra-epithelial leukocytes in the chicken digestive tract: phenotypical characterisation in situ. Cell Tissue Res. 274, 295-301.

Waterland, R. A., Dolinoy, D. C., Lin, J. R., Smith, C. A., Shi, X. and Tahiliani, K. G. (2006): Maternal methyl supplements increase offspring DNA methylation at axin fused. Genesis $\mathbf{4 4}$, 401-406.

Waterlow, J. C. (1996): The requirements of adult man for indispensable amino acids. Eur. J. Clin. Nutrition 50, S151-176.

Wu, B., Cui, H., Peng, X., Fang, J. and Liu, X. D. (2012a): Effect of methionine deficiency on the thymus and the subsets and proliferation of peripheral blood T-cell and serum IL-2 contents in broilers. J. Integr. Agr. 11, 1009-1019.

Wu, B., Cui, H., Peng, X., Fang, J., Cui, W. and Liu, X. D. (2012b): Pathology of spleen in chickens fed on a diet deficient in methionine. Health 4, 32-38.

Wu, B., Cui, H., Peng, X., Fang, J., Cui, W. and Liu, X. D. (2013): Pathology of bursae of Fabricius in methionine-deficient broiler chickens. Nutrients 5, 877-886.

Yang, H., Sadda, M. R., Li, M., Zeng, Y., Chen, L., Bae, W., Ou, X., Runnegar, M. T., Mato, J. M., and Lu, S. C. (2004) S-adenosylmethionine and its metabolite induce apoptosis in HepG2 cells: Role of protein phosphatase 1 and Bcl-x. Hepatology 40, 221-231.

Yen, C. L., Mar, M. H., Craciunescu, C. N., Edwards, L. J. and Zeisel, S. H. (2002): Deficiency in methionine tryptophan isoleucine or choline induces apoptosis in cultured cells. J. Nutr. 132, $1840-1847$. 